\title{
Teaching and Learning Within Inter-Institutional Spaces: An Example from a Community-Campus Partnership in Teacher Education
}

\author{
Cher Hill, Paula Rosehart, Sue Montabello, Margaret MacDonald, Don Blazevich, \\ Belinda Chi
}

\begin{abstract}
This paper explores the potentiality inherent within a community-campus partnership in the area of inservice teacher education, and the inter-institutional space that has afforded creative and collaborative practices. Through this partnership, we endeavour to find innovative ways to better serve our students and create opportunities for smooth interactions and flow across school and university communities. Unlike other research that explores tensions and/or common ground within community-university partnerships, we seek to understand the potential that is created in the metaphorical space in-between institutions. Using dialogic inquiry, the diverse members of our teaching team, including members of the university community and the K-12 school system, as well as graduates of the program, reflected on the unique material, discursive and relational dimensions of our inter-institutional space. We came to see our graduate program as a hybrid place of connections, rhythms, and intersections in which usual institutional practices are ruptured. Together we identified powerful interrelated structural dimensions of our inter-institutionality, which we referred to as the gathering space, the inquiry space, the transformative space and the empowering space. These themes and the flow that has been created across and between institutions will be discussed in the following paper.
\end{abstract}

KEYWORDS community engagement; community-campus partnership; inter-institutional space; teacher-education, third space

Despite common challenges associated with cross-institutional partnerships, such as fostering relationships, harmonizing differences, and calibrating goals, university-community collaborations can encourage innovation and social change (Mandell \& King, 2014; Langan \& Morton, 2014). Within the field of education, collaborative school-university partnerships can be viewed as a social practice, whereby the sharing of knowledge is democratic, reciprocal, sustainable, and mutually beneficial (Chan, 2016). In this way school-university partnerships can serve to support educational reform efforts (Borthwick, Stirling, Nauman, \& Cook, 2003). As Groundwater-Smith, Mitchell, Mockler, Ponte, and Ronnerman (2013) contend, in order for relationships between the academy and school education to be reciprocal (as opposed to transactional), there is a need to acknowledge that "the boundaries between actors 
are of a far more permeable nature than has been hitherto recognised" (p. 2). Thus, within the collaborative partnership there is flow and respect for different yet mutually beneficial types of knowledge, theory, pedagogy and practice shared by practitioners in the field and faculty at the university level. While much research has targeted the tensions inherent within university and school partnerships focused on supporting teacher professional learning (Kersh \& Masztal, 1998; Yappa, 1998; Catelli, Costello, \& Padovano, 2000; Day \& Smethem, 2010), and the importance of working towards common goals (Borthwick, 1994; Whitford, 1996; Hopkins, West, \& Ainscow, 1998), our work goes beyond investigating tensions and transactions between institutions to explore the transformative nature (Groundwater-Smith et al., 2013) inherent within the space in between schools and the university.

In this paper, we explore our community-campus collaboration and the potential of our inter-institutional space. Our graduate level, inservice teacher-education program is a shared endeavour between a university and various school districts in which curriculum and pedagogies are co-constructed and artefacts from the different institutions assemble in unique ways. As such, the program resides in a liminal, or what we refer to as an inter-institutional space, resulting in not only creative collaborations, but also intersections and ruptures that enable novel lines of flight (Deleuze \& Guattari, 1987), and new ways of being and becoming for the community members inhabiting these spaces. In his poem entitled The Uses of Not, Lao Tzu ${ }^{1}$ illuminates how empty spaces - for example, in between the spokes of a wheel or the walls of a house-form the essence of the thing. It is the potentialities within these in-between spaces that captured our imagination as we explored and theorized our cross-institutional practice.

\section{Context}

Simon Fraser University (SFU) endeavours to be the "leading engaged university, defined by its dynamic integration of innovative education, cutting edge research, and far-reaching community engagement" (Simon Fraser University, n.d.). This value is actualized within the work of the Field Programs unit, housed within the Faculty of Education at SFU. Established in 1984, Field Programs has been facilitating in-service teacher education, in partnership with school districts and communities, for over 20 years. Our graduate programs, including the Graduate Diploma in Advanced Professional Studies in Education (GDE) and the Masters of Education in Educational Practice (M.Ed. EP) provide opportunity for teachers to engage in sustained reflective inquiry into questions that stem from their own professional practice. The graduate diploma program is unique in that various offerings are developed through community-campus collaborations involving representatives from school districts, communities and the university. For example, our program Indigenous Education: Education for Reconciliation was a collaborative endeavour undertaken by the university, a school district, and the Squamish and Tsleil-Waututh Nations. Our instructional teams embrace academic scholarship, as well as professional knowledge and expertise, and include 'master' teachers seconded from school districts (known as Inservice Faculty Associates), university professors, and practicing K-12

\footnotetext{
${ }^{1}$ The Uses of Not by Lao Tzu can be found on the blog, "A year of being here: Daily mindfulness poetry by wordsmiths of
} the here \& now," available: http://www.ayearofbeinghere.com 
teachers who serve as mentors. In this way, traditional hierarchical epistemological relationships between the university and the community (Van Katwyk \& Case, 2016) are disrupted.

Our programs are based on a practitioner-inquiry methodology in which teachers engage in the intentional, disciplined study of their own practice (Cochran-Smith \& Lytle, 2009; Dana \& Yendol-Hoppey, 2014). In the GDE program, teacher-learners engage in field studies while simultaneously participating in course-work focused on a particular theme, such as Inclusive Education, Indigenous Education, or Exploring Maker Pedagogies. This curriculum enables teachers to work at the very intersection of theory and practice within their own professional context, catalyzing new ways of thinking, doing, and being for themselves, their students, and their communities. Our pedagogy is based on a mentorship model that facilitates the development of learning-focused relationships. Cohorts typically meet once a week, outside of the university within school settings, to support one another in developing and enhancing critical, creative and reflective practice. Our programs are typically highly impactful, enabling teachers to transform themselves personally and professionally and make powerful shifts in their practice (Hill \& MacDonald, 2016).

Within our current roles, some of us are primarily affiliated with the school district (Belinda, Don and Sue), while others are primarily affiliated with the university (Margaret, Paula and Cher). Many of us have held various roles and affiliations over the years and some of us hold multiple positions simultaneously. Belinda and Don are elementary school teachers, alumni of the GDE and M.Ed. EP programs, as well as mentors and instructors in the diploma program. Margaret is an Associate Professor, a former Director of the Field Programs unit, and a former elementary school teacher. Sue is a retired high school principal, a former Faculty Associate, and a long time instructor in the Faculty of Education at SFU. Paula is an Academic Coordinator and an instructor in Field Programs. She was an Inservice Faculty Associate, mentor, and instructor in the GDE, as well as a primary teacher, and is an alumna of the Graduate Diploma program. Finally, Cher is an Assistant Professor of Professional Practice, an Academic Coordinator, and instructor within the Field Programs unit.

\section{Theoretical Framework}

As educators, we live and work in structures that can be antithetical to who we are trying to become and how we imagine doing so. Over the years, post-structural philosophers like Derrida (see Captuo, 1977) and Foucault (1977) have helped us understand the connection between social and political systems and our ways of life. Seeking deeper understandings of the challenges and barriers that restrict our creativity can be emancipating, but only if we take the next step in seeing openings as potential ways to get beyond restrictive and constraining structures. Openings like Barad's (2007) discussion of Quantum Field Physics can be deceivingly powerful. There are times that openness like a vacuum or a void has imminent power because of its potential. In its nothingness - it holds every possibility. In our lives we are often eager to fill emptiness and tend to consider a full life as a hallmark or measure of success. In our drive to fill our lives in a satisfying way we often rush past the emptiness and don't take the time to consider these spaces as possibilities, the space between the spokes in 
the wheel that are necessary to the whole.

Theoretical conceptions of liminality, including Bhabha's (2004) notion of the third space and Jackson and Mazzei's (2012) notion of thresholds illuminate the potentiality inherent within in-between spaces. Bhabha (2004) conceptualizes the space between cultures as hybrid, fluid, and ambivalent. Within this third space, "the mirror of representation" (p. 54) is disrupted and cultural knowledge can be "appropriated, translated, rehistoricized, and read anew" (p. 55). Similarly, Jackson and Mazzei (2012) conceptualize thresholds as structureless voids in which difference becomes possible:

In architecture, a threshold is in the middle of things. It exists as a passageway. A threshold has no function or purpose, or meaning until it is connected to other spaces. That is, a threshold does not become a passageway until it is attached to other things different from itself. Thresholds contain both entries and exits; they are both/ and. A single threshold can be not only an entryway, but also an exit; therefore the structure itself is not quite as linear and definitive as one might think. In other terms, thresholds can denote excess, such as having a low threshold for pain. The excess of a threshold is the space in which something else occurs: a response, an effort, an effect. Once you exceed the threshold, something new happens. (p. 6)

In-between spaces are simultaneously hybrid intersectionalities (of both), as well as vacuumous gaps (of neither) where an infinite number of potentialities can be actualized (Bhabha, 2004; Jackson \& Mazzei, 2012). Within the infinite exists a power, excitement, foreboding and movement. Here institutional identities and practices can be disrupted, contested, and re-envisioned.

Inter-institutional spaces are what Deleuze and Guattari (1987) would call smooth spaces, in which movement is heterogeneous, open and fluid (akin to water traversing a flat surface, spreading out in indeterminate directions), as opposed to striated spaces, in which movement is homogeneous, linear and defining (similar to the flow of water channelled within a trench). Within this conceptualization, the striated spaces through time can be thought of as the constraints, regulations or structures that educators reside with and abide by. Within schools and universities we as practitioners come to know them and consider them as we navigate our relationships and practices. Institutional policies, regulations, physical constructs, and other binding pressures have built up to both define us and in theory protect us. In part, this has been the result of the many political and legal requirements, safety concerns and an overall ethos of standardization and 'best practice' constituted under the guise that homogeneity may lead to consistent quality, standard epistemological practices and, in theory, better outcomes.

In progressing toward uniformity and a shared knowing, being and doing within striated layers, flow and movement however, are also limited. Over many years, striation has grown and expanded like a coral reef creating pockets that can both protect but often (intentionally) constrain passage. How can fluidity, movement, growth and creativity within these striations prevail so that teaching, learning and our engagement with the world is not merely facilitated 
safely and conducted homogeneously, but is also mutually inspiring, rewarding, generative, creative and emancipating?

\section{Method}

In order to better understand our campus-community partnership, we engaged in a dialogic inquiry (Arizona Group, 2006; East, Fitzgerald, \& Heston, 2009; Himley, 2000; Tidwell, Heston, \& Fitzgerald, 2009), in which we met on a regular basis over a period of six months to examine our experiences grounded in our unique long-term perspectives as educators, administrators, and students, and theorized our pedagogies and practices within an intersubjective field (Heron \& Reason, 1997). Himley (2000) calls dialogue "human capacity, widely distributed" (p. 199). She says, "When the talk is collective and sustained and respectful, its power is enhanced by the differences among people and by the recognition of multiple perspectives in deciding how to act in the world" (p. 199).

The fact that we are differently positioned and have occupied multiple roles within our community added to the richness of our dialogues. The common world we share is the inter-institutional community, a diverse group of master learners who come together to seek collegiality, renewal, support, and a new pathway forward through the educational landscape. We have found dialogue to be a powerful method of self-study in which new knowledge emerges (Arizona Group, 2006; Tidwell et al., 2009). As noted by a member of the Arizona Group (2006), "I come to know what I know as I say it" (p. 61). We would add that we also came to know what we know by being challenged in our perspectives as we question our assumptions and our values.

Our dialogic practices have been honed over our years as professionals, living and working in spaces like SFU and within the school districts, where dialogue is valued as part of our democratic and intellectual capacity building practices. In this, we were mindful to establish ground rules, such as maintaining confidentiality, asking open and authentic questions, as well as valuing individual experiences, as recommended by Tidwell et al. (2009) in order to facilitate group process, enhance participation, encourage the collaborative development of ideas, and to respect divergent perspectives.

Over six sessions we explicated, explored and refined our collective ideas about our campus-community partnership. Although we set out primarily to study our challenges and felt tensions, we also found smooth openings through dialogue where strategies for working within inter (and intra) institutional constraints to achieve our shared goals, were realized. The potential inherent within our interconnectedness was liminal, a vacuum, an opening. Our group became predominantly focused on the in-between spaces, intersections and gaps that created affordances across our campus-community partnership that were laden with potential for creating flow and movement.

Perhaps we found these spaces out of a sense of survival, knowing that we had been successful in achieving flow and movement and navigating restrictive caverns that we recognized, respected but didn't become enveloped by. Through dialogue about our day to day collaborations and a diffractive wayfaring (see Hill, 2017) related to how we worked 
through enabling constraints (Fels \& Belliveau, 2008), we addressed the inherent tensions within our institutional practices to arrive at deeper and different understandings of how our collaborations and partnerships, helped us rally against neo-liberal agendas that impinge movement in their call for efficiencies, risk management and standardization. We conveyed our passages and flow against this backdrop as we focused on the aspects of our work that are life-giving and sustaining, generative and creative.

Our discussions helped us understand the power and potential that we had felt within our relationship and focused not on the restrictions that are inevitable within institutions (over time and with increased governance), but the moments where success appeared in the liminal openings that were creative, powerful, and smooth - our moments of flow. We focused primarily on the space we held in common, the space between the university and the K-12 school system. Here we recognized that there are powerful inter-institutional spaces within the university and schools, which hold their own tensions and synergies, power and potential. We began with the following initial set of questions:

- What does it mean to be engaged in community to university relationships; to engage in "cross-institutional practices?" What is our lived experience in this regard?

- What are our commonalities? Our points of convergence?

- How does our inter-institutional relationship contribute to the common good? In what ways is our partnership generative?

- What are our inter/institutional tensions? Our points of divergence?

- How have we or how could we address such tensions?

- What barriers, disconnects, affordances, and potentialities do we experience in terms of space, locations, language, assumptions, perceptions, policies, practices, etc?

- What metaphor/image/feeling(s) might capture the nature of our inter-institutional work?

All six meetings, which were typically two hours in duration and included all of the co-authors, were recorded and transcribed (or otherwise documented). We analyzed the transcript of our first meeting for recurring themes and what Tidwell et al. (2009) call "recalibration points" nodal moments in which ideas crystalize. These key ideas were then explored in subsequent sessions, and further explicated and connected to practice through theory, images, metaphor, narratives, and/or poetry. We collectively theorized the insights that emerged from our iterative process of dialogue and analysis, and wove these understanding into the following rendering, which reflects our shared voice.

\section{Findings}

Through our multimodal methods, we theorized the unique material, discursive and relational dimensions of our inter-institutional space. We came to see the space in-between the university and schools as liminal and open: inviting hybridity, connections, and intersecting rhythms, as well as a paradoxical space of incongruencies. It is simultaneously within a universitysubject to the institution's governing policies, and not within a university-adopting many 
K-12 pedagogical practices. It is both in a school, held within the spaces where teachers work, and not within a school, bringing teachers together in atypical ways. Cohorts typically meet in school libraries, creating an intermediate space between the students' roles as teachers and as learners. This space is within the school and yet outside the teachers' classrooms, creating a corporeal threshold, a space where we connect the two worlds. In this way, it enables us as teacher-learners to live in-between as we both affirm and question our collective practice and together explore the possibilities of our work in schools. In the words of Noddings (2002), the space became an "intermediate place that prepare[d] us for life in a larger world" (p. 173).

Within our context, working inter-institutionally unsettles and disrupts typical intrainstitutional practices and interactions, creating uncertainty, as well openings for new ways of being to co-emerge. As Cher noted, working between the school and the university "pulls people outside of their culture - we come to question our usual practices, and can ... identify common tensions - concerns we might not see if we stayed within one institution." As the program brings together teachers from different districts, as well as members of the university community, we as teachers and learners escape our own institutional echo chambers. Through the provocation of other, we see and hear differently and come to deeper understandings of our own cultural contexts. As Bakhtin (1986) contends, "meaning reveals its depths only once it has encountered and come into contact with another" (p. 7). As such, when educators from different institutions come together to share lived experiences, practices that are normalized within specific institutions become evident, and we come to understand that some of our frustrations are not idiosyncratic but rather systemic in nature (Brookfield, 1995).

During our dialogues, we explored how this in-between space enabled a different way of connecting, a different way of engaging, as well as different opportunities for being and becoming in the world. Nodal moments (Tidwell et al., 2009) revealed powerful structural aspects of our inter-institutionality, which we began to refer to as the Gathering Space, the Inquiry Space, the Transformative Space, and the Empowering Space. Although we talk about them as distinct spaces, these thresholds are all inter-related and entangled like a root bridge in which boundaries between distinct roots can be both traced and collapsed-creating a visual in which the roots are simultaneously distinguishable and indistinguishable_-and forming a whole that is greater than the sum of its parts. These aspects of our pedagogical practice are described in the following section in relation to our inter-institutional context.

\section{The Gathering Space}

Within our hybrid space, institutional hierarchies and roles are deconstructed and teachers and learners come together to create networks of support, reciprocal relationships and an interdependent culture. As Don said, "It is a gathering. It is not a coming to receive. It is a coming together with respect, such as when the Nations come together. You trust, drop your guard, knowing that whatever you bring is valued. These are your people, they understand, they can help. There is a lot of trust, a community." When we focus not on our roles, but our relationships, we come to understand the interconnectedness of our work together. The sense of community in the graduate diploma in advanced professional studies in education builds a 
structure of belonging (Block, 2009) that strengthens teacher's confidence and agency to ask really big questions, such as, "How do we transcend the institution as we work together to transform our individual and collective practice in schools?"

When we as teachers and learners step away from the institutional space of the school, where we are known through our roles, we also move beyond the expectations or judgement of our colleagues and administration. As Sue noted, "all too often our own voices become lost within the relentless demands and judgements of the institution. Sometimes we are stuck waiting for the organization to give us permission." Being away from the institutional space also means being away from staff meetings, committee meetings, team meetings and parent meetings. These types of meetings all come with agendas, scripts, and sometimes, workplace politics. Moving outside of institutional spaces allows for us as educators to share more openly and speak our minds (and our hearts). As we transcend the institutional threshold, our role shifts. When we come into the inter-institutional space, we arrive as teacher-learners. With us, are other like-minded individuals who are bonded by the weekly readings, ponderings about our own educational philosophies and the common experiences we share with our students. The time we spend together as teachers and learners helps us transcend our own institutional cultures, as we move into the inter-institutional space of a safe community without judgment. Within this liminal space, there is mutual respect and understanding. Scholarship here serves as a provocation (Malaguzzi, 1994) that weaves a different set of relationships among teachers and ignites a different sort of conversations than what typically occurs in schools. Scholarship within the gathering space serves as a "third thing" (Palmer, 2009), representing neither the voice of the facilitator, nor the voice of the participant that catalyzes potentialities:

True community in any context requires a transcendent third thing that holds both me and thee accountable to something beyond ourselves...The subject-centred classroom is characterized by the fact that the third thing has a presence so real, so vivid, so vocal, that it can hold teachers and students alike accountable for what they say and do. (p. 119)

As teachers come together in the GDE program, the cohort gradually becomes a new type of community atypical of most institutions, one that is both professional and collegial. There is a sharing of current professional practice that both encourages and supports us as individuals on our journey toward improving our teaching practice. Rachel Kessler's (2000) conception of the teaching presence speaks to the idea of an open heart that "allows a teacher to be trustworthy and to help build trust in the group...to be vulnerable and be willing to care" (p. 8). She continues to remind us that when we know our vulnerability will be both respected and protected, it is then we may become more deeply connected to ourselves and to one another. If we are to be honest in our work as reflective practitioners, it is essential that we open ourselves to others and share the tensions we experience as we explore our practice and not keep silenced what we may consider to be a failure in the attempt to try something new in our classrooms. The supportive words of a trusted colleague may be all we need to sustain

Engaged Scholar Journal: Community-Engaged Research, Teaching, and Learning 
ourselves along the path of growth and self-discovery.

When we question our work together in community with an open heart (Kessler, 2000), we bring together our collective wisdom and understanding. We begin to ask questions that move beyond the individual and are connected to the larger whole. We begin to ask questions that have the potential to transform our work within the broader system. Within the gathering space, we are no longer seeking permission; rather we are coming together as likeminded people with a shared intentionality. Like a pile of twigs that radiate from the centre outwards in different directions, teacher-learners move from the gathering space, back into the world with a grounding that permeates practice. As Belinda noted, "there is a confidence and strength that emerges from those conversations that you take back with you [into your school]".

The instructional practice in Field Programs intentionally shifts the learning and teaching space to move away from the traditional hierarchical structure toward a community of practice (Lave \& Wenger, 1991). Communities of practice are formed when people come together to engage in a process of collective learning around a common practice. As Wheatley (2009) contends:

As we share our different experiences, we rediscover a sense of unity. We remember we are a part of a greater whole. And as an added joy, we also discover our collective wisdom. We suddenly see how wise we can be together. (p. 32)

Engaging with one another in communities of practice acknowledges the networks and interdependence of relationships that contribute to collective practice. Learning in this way creates a shared space for emerging relationships and meaning making, creating a diverse exchange of experience and learning. Central to this shift is the concept of collectively holding space where "the leader's real work is to help people discover the power of seeing and seeing together" (Scharmer, 2009, p. 132). Holding space consciously facilitates deep reflection and shared sense making with an open mind and heart. At the heart of holding space are conversations that "create a generative social field" that connect individuals to a "deeper sense of their journey and their Self" (Scharmer, 2009, p. 187). This centrality of conversation as a means to know and understand our individual and collective practice relates to David Bohm's (1996) notion of dialogue:

The picture or image that this suggest is a stream of meaning flowing among and through us and between us. This will make possible a flow of meaning in the group, out of which may emerge some new understandings. It is something new, which may not have been in the starting point at all. It's something creative. And this shared meaning is the 'glue' or 'cement' that hold people and societies together. (p. 6)

Opening our hearts and minds to the deeper sense of their journey and their Self that Scharmer (2009) speaks of requires a vulnerability. It is only within caring relationships and community that this vulnerability finds voice. Caring means seeing the other in his or her own 
terms (Noddings, 1984). Dialogue strengthens and supports Nodding's notion of care. She contends, "When people talk and listen to one another in this way, trying to understand each person in their own terms, they tend to develop caring relationships" (p. 186).

The purpose of dialogue is not to merge the many different views of group members into one but rather the point of dialogue is simply the sharing of the mind (Bohm, 1996), and, from our experience, the heart. In this way, both the individual and the collective are given voice. Holding space for this dialogue where both the heart and mind are opened enables teachers to think and work together within communities of care, deepening their understanding and connecting to their imagination of what is possible, merging together into a collective stream of meaning (Bohm, 1996). Teachers deeply value this space, which is rarely possible within the demands of day-to-day school life. In our experience, holding space in this way returns us to the intentionality of our practice as teachers, helping us remember the calling of our work.

\section{The Inquiry Space}

The graduate diploma in advanced professional studies in education program is based on an inquiry methodology in which teachers study their own professional practice (CochranSmith \& Lytle, 2009; Dana \& Yendol-Hoppey, 2014). Within this space, teacher-learners are encouraged to critically reflect, explore and ask questions that are personally/professionally relevant, and to consider multiple lenses when examining the impact their epistemological and ontological leanings have on those they teach. Practitioner inquiry can be both disciplinarybased, which results in "new understandings of existing disciplinary norms and/or the creation of new knowledge" or inter-disciplinary-themed, which results in "fresh understandings of wise practice and classroom intelligent action" (Grimmett, 2014, p. 4). In this way, there is a certain "freshness in the knowledge dealt with; it is either new itself or invested with some novelty of application" (Whitehead, 1929, p. 98). Within our inter-institutional space, teachers work at the very intersection of theory and practice. Scholarship is taken up in powerful ways and dissemination is atypical compared to common practices within the university culture. Here theory is enlivened, animated, as well as contested and reworked, and subsequently shared - often orally via workshops and through mentoring relationships.

Working inter-institutionally, inquiry takes on a different form than when working within striated institutional spaces in which the foci of professional learning is often mandated, and/ or the outcomes are predetermined. Within school districts, there is usually a professional development committee that identifies the focus of the school's professional development for the year. This committee is comprised of administrators and teachers who are interested in leading their staff and school into a specific direction. In many ways, having a committee decide the focus each year is beneficial for teachers as they can follow what someone else has planned out for them. It follows a 'script', as teachers are usually given many tools and suggestions as to what they could do in their classrooms on the chosen topic. For example, a professional development committee might suggest that the staff should focus on SelfRegulated Learning. A teacher may take the suggested activity of creating anchor charts with their students. That teacher might execute the lesson in their classroom, create the anchor chart 
with their students, tape up the poster on the wall, and then say that they have done it and are ready to move on. As Margaret noted, for some teachers, "the institutional focus allows for people to check things off as 'done', rather than to fully explore what might be, if they were to ask questions deeply related to their own practice." This relates to the role of theory and the value of being guided by and versed in educational theory to deeply understand whether or not the suggested activity or activities are in alignment with the teacher's philosophical outlook and consistent and compatible with the teacher's world view, and are meaningful within the specific context.

The mess and complexity of learning that is not institutionally prescribed often requires that we go 'off script'. This occurs as we allow ourselves to explore, to try new approaches, and to take risks. Trusting our colleagues and embracing the smooth space where we meet in the GDE program, we learn to 'trust the mess' as a part of that journey. Going off-script often feels risky and uncertain; however, it is an allowing. It enables learning to flow like water on a flat surface, dispersing in unanticipated directions, and for practice to advance in unexpected ways. That "mess" of inquiry lives within the school, but can be deconstructed and examined in all its complexity within the space in-between institutions.

Rather than relying on institutional authority, teacher-learners in the GDE program are encouraged to develop their own capacity to evaluate their practice as educators and develop an inner compass that guides complex decision-making. Here, as Belinda would say, expertise is "pushed off on to learners." As Don explained, "Initially teachers are passive, waiting to receive. When they come to understand that they get to guide their learning - it is an awakening."

Critically creative reflection, self-study of practice, self-assessment, non-graded learning, formative feedback, and critical friendships are foundational underpinnings that support teacher-learners' growth. The teachers in the GDE program self-assess their professional growth by continually evaluating themselves against a set of programmatic capacities, holistic ways of knowing, doing, and being (McDiarmid, 2008). These 'dispositions' are seen as potentials for professional learning. For example, one cross-program capacity includes the ability to develop a disposition of inquiry, and critical reflection to understand and develop effective teaching practices. This capacity invites teachers into contemplative examination of their practice and encourages innovation, experimentation, and the exploration of scholarship in order to revise pedagogical approaches. Thus, the embodiment of the capacities as ways of knowing, being, and doing are open, reflexive in nature, and require teachers to self-assess their growth, becoming creative and curious practitioners. This non-graded graduate learning is atypical in the university, where the pressure to maintain rigour within assessment through standardized grading practices has been increasing exponentially.

Rather than being institutionally mandated, inquiry work within our liminal space is invitational. As Block (2009) contends:

Invitation is not only a step in bringing people together, it is also a fundamental way of being together in community....An invitation is more than just a request to attend: it is a call to create an alternative future, to join in the possibilities of our work together. (p. 172) 
Teacher-learners have to be willing to take the journey to learn. Answers are not given; they are discovered by the learners themselves. Students who are willing to take that journey to examine their own practice gain a valuable education with regards to who they are as teachers and learners. The knowledge they gain is knowledge about themselves, along with membership within a community of educators, grounding them in their educational philosophy and their teaching practice.

One of the most distinct features of the graduate diploma program is how teacherlearners are encouraged to examine "the self who teaches" (Palmer, 2007, p. 7) and to reflect deeply on themselves as practitioners. In this way, personal and professional boundaries are often collapsed creating a holistic (Miller, 2007) and often powerful transformative learning experience. Through self-exploration, and co-construction of knowledge and practice, there is an insider way of knowing through inquiry - a dance between subjective and local knowing. In a supportive community (sharing, discussing, reflecting), we once again find strength in who we are (Palmer, 2007), and begin to see potential in allowing ourselves to be vulnerable (Brown, 2012). Within the inter-institutional space, inquiry is situated within the self, inviting more intimate and personal understandings that may not occur within traditional institutional spaces that often demand professionalism (Noddings, 1992).

\section{The Transformative Space}

As thresholds give way to undefined indeterminate, smooth spaces, subjectivities and identities shift and new ways of becoming are actualized. Transformations, often surprising and unexpected, commonly occur within the inter-institutional space of our graduate program. In the following narrative, Paula describes her own experience as a student in the graduate diploma in advanced professional studies in education program, which "opened up a world of possibilities for [her] as an educator, a professional, and as a person." Completing the GDE gave Paula the confidence to pursue a Masters degree and a later $\mathrm{PhD}$, as well as seek leadership positions as a teacher-educator. Paula's narrative exemplifies the openings and potentialities inherent within inter-institutional spaces, such as Field Programs:

\section{A Mobius Strip Moment}

Field Programs for me was both personally and professionally transformative. Like the Mobius strip, my 'two sides': inner and outer, personal and professional, student and teacher, artist and educator, became one. The inner-outer connections I made between my values and philosophies as a teacher and my practice became more closely aligned, more seamless. The Graduate Diploma in Education provided a space where I could reflect inwardly on my autobiography as a learner and educator and inquire outwardly to contemplate and examine how these ways of knowing, being, relating and learning were at unity with my practice. It was a sort of homecoming. As T.S. Eliot (1942) extols, "the end of all our exploring will be to arrive where we started and to know the place for the first time" (para. 14). I came to know and acknowledge my creativity, gifts and talents in a novel and unique way, a way which honoured my learning spirit (Battiste, 2013). The powerful, experiential, embodied teaching/learning experiences,

Engaged Scholar Journal: Community-Engaged Research, Teaching, and Learning 
"facilitated learning in which I was able to deeply integrate what I was studying" (Miller, 2010, p. 31). The invitation to learn, explore, and discover through the arts opened up a world of possibilities for me as an educator, a professional, and as a person. As I was developing my knowledge and skills in the arts, I was developing myself, my credo, and my confidence as a learner and an educator. For the first time in a long time, since I was a misunderstood girl at the arts school, I felt capable and successful as a learner. The methods employed in the program, the programmatic philosophy, spoke to me and moved me forward, and allowed me to follow a wellmapped out direction. As a learner, I was given respect and what I would like to call 'freedom within a framework', as though I were laying down a foundation and constructing my practice with my own hands and body (Rosehart, 2013). "I began to reflect critically on my own practice and examine more thoughtfully the powerful role that the arts played in the teaching and learning process. I felt more capable of creating meaningful artistic experiences for my students and developed the ability to integrate authentically the arts into my practice" (Rosehart, 2013, p. xxi).

Like the Mobius strip, I was able to connect my learning spirit (Battiste, 2013) with my teaching spirit. As Leggo (2008) so eloquently reminds us, "There is no need to separate the personal from the professional any more than we can separate the dancer from the dance. The personal and the professional always work together, in tandem, in union, in the way of complementary angles" (p. 5). In this way, the program brought me home to myself.

Professional exploration within our inter-institutional space enables members of our community to share more openly, speak their minds within a safe community where judgment is withheld, and there is mutual respect and understanding, potentially enabling transformation. As exemplified above, within this space we have the opportunity to re-imagine our practices, be ourselves, and explore potentialities. The work we do within our inter-institutional community re-inspires us and gives us strength to grow and transform as individuals. When we name and examine the shared humanity of our work alone and together, the collective conversation has the potential to return us to a place of intentionality remembering why we went into teaching in the first place. There is a path to becoming reconnected to one's self, a way of knowing that becomes grounded in theory, which strengthens and affirms our practice. As Sue observed, "People who have lost their lustre in the work because of institutional demands [are] brought back to this place of intention. They are re-inspired with hopefulness to continue, and find confidence through connections with others." Within these spaces educators are transformed, come back to themselves, or become more grounded, confident, and affirmed in their practice (see Hill \& MacDonald, 2016).

\section{The Empowering Space}

Our liminal space in-between the university and school districts is akin to what Waldrop (1992) refers to as "a space of interaction - a space of imagination. . . a place where a complex system (people) can be spontaneous, adaptive and alive" (p. 12). The K-12 inservice teachers enter 
the program seeking renewal, collegiality, challenge and stimulation, as well as certification. We endeavour in Field Programs to co-construct communities of practice, to create a place where teacher-learners can express their feelings, ideas, questions, traditions, beliefs, and customs, and become empowered as practitioners, and to create a 'brave space' (Arao \& Clemens, 2013) where learners can thrive.

The GDE program provides the space, or more specifically, the institutional 'permission' (as sanctioned by the university) to explore one's practice. A feeling of empowerment encourages teachers to focus on what is important to stimulate growth in relation to their own practice. The path of self-directed inquiry, grounded in research, sustained through reflection and sharing is what brings value and commitment to the journey. The ungraded nature of the GDE program further creates space for deeper engagement and work that really matters. Through a recursive, reflective, inquiry cycle, such questions as, "Is this enough. Am I enough?" are often asked. It is where vulnerability strengthens the practitioner. Removing the focus from grades to process is freeing and liberating in pursuing a self-directed path of inquiry as a teacher-practitioner.

The structures of the school where a teacher practitioner is employed may not always align with these same intentions. There are many factors that exist in schools, such as school goals, administration support, district goals, timetabling, resource allocation, and funding which are inherently designed to meet the needs of the school. Institutional constraints that are dictated or expected may stifle, or "throw a cage", as Don would say, over teachers' agency. We have found however, that as teachers become deeply engaged in their inquiry while working alongside colleagues to situate emerging knowledge and beliefs, a sense of ownership, voice, and agency emerges. It is from this place that they begin to challenge the structures of schooling that no longer serve children and move toward changing these structures in their classrooms and beyond. Finding agency to question the system that we are in, through inquiry, conversations, readings, and playful irreverence, opens doors to new possibilities. Creative maladjustment is the art of resisting the demands of the system that are inequitable and unjust while still remaining caring and compassionate (Kohl, 1995). It does not however, stand on its own but is embedded in the process of naming, examining, resisting and transforming (in community) that Maxine Greene (1988) speaks of in her work: "We need to create public spaces in which we can openly appear before one another as who we are - to name, to examine, to resist, to transform and ultimately embrace our world" (p. 115).

The following poem, written by Belinda, entitled Between, highlights many of the potentialities for being and becoming inherent within our liminal, hybrid, inter-institutional space, and speaks metaphorically to the empowering and transformative lived experiences we strive to create in Field Programs. 


\begin{tabular}{|c|c|c|}
\hline & between & \\
\hline $\begin{array}{l}\text { in here } \\
\text { a teacher }\end{array}$ & I am & $\begin{array}{l}\text { in there } \\
\text { a learner }\end{array}$ \\
\hline $\begin{array}{l}\text { in here } \\
\text { staff meetings }\end{array}$ & I attend & $\begin{array}{l}\text { in there } \\
\text { conversations }\end{array}$ \\
\hline $\begin{array}{l}\text { in here } \\
\text { about rubrics }\end{array}$ & I learn & $\begin{array}{r}\text { inthere } \\
\text { about my practice }\end{array}$ \\
\hline $\begin{array}{l}\text { in here } \\
\text { emails fromcolleagues }\end{array}$ & I read & $\begin{array}{r}\text { inthere } \\
\text { articles thatground me }\end{array}$ \\
\hline $\begin{array}{l}\text { in here } \\
\text { report cards }\end{array}$ & I write & $\begin{array}{r}\text { in there } \\
\text { about my learning journey }\end{array}$ \\
\hline $\begin{array}{l}\text { in here } \\
\text { the school goals }\end{array}$ & I review & $\begin{array}{l}\text { inthere } \\
\text { mygoals }\end{array}$ \\
\hline $\begin{array}{l}\text { in here } \\
\text { on the situation at recess }\end{array}$ & I reflect & inthere \\
\hline $\begin{array}{l}\text { in here } \\
\text { the majority }\end{array}$ & I follow & $\begin{array}{l}\text { inthere } \\
\text { myheart }\end{array}$ \\
\hline
\end{tabular}

\section{Conclusion}

The Field Programs unit within the Faculty of Education at Simon Fraser University is a threshold of sorts between the university and the school districts. Between these institutions resides a liminal, undefined, smooth space in which restrictive and constraining structures can be disrupted and an infinite number of potentialities can be actualized. It is a space characterized by dimensions of relationality, inquiry, transformation and empowerment that 
extend rhizomatically outwards, breathing new life into practice. Something extraordinary occurs in this space - institutional roles, scripts and hierarchies are ruptured, collaboration and autonomy are heightened, vulnerability, risk taking, tenacity, and creative maladjustment (Kohl, 1995) are encouraged, and teachers grow into themselves, come back to themselves, and become grounded within themselves, as well as within their learning communities. Despite ongoing inter (and intra) institutional tensions that often consume much energy requiring innovative work-arounds and creative problem solving within our inservice, graduate level teacher-education program, we have come to appreciate the way in which our inter-institutional partnership creates a space that invites a different sort of engagement and inspires teachers to think differently about their practice and to catalyze change within their classrooms and communities. Focusing on the creative forces within our campus-community collaboration has enabled us to look beyond our tensions and common goals to recognize the transformative potentiality inherent within the spaces in-between.

\section{About the Authors}

Cher Hill (corresponding author) is an Assistant Professor of Professional Practice and the Coordinator of the MEd and EdD programs in Educational Practice in the Faculty of Education at Simon Fraser University. Her primary areas of expertise include practitioner inquiry, reflective practice, and in-service teacher education. Her current research utilizes new materialist theories to go beyond reflective practice and invite diffraction into the field of professional learning. Email: chill@sfu.ca

Margaret MacDonald is a former Director of Field Programs and an Associate Professor at Simon Fraser University whose research interests include Intergenerational Programs, Pedagogical Documentation, and Curriculum Development in early childhood education. As part of her intergenerational focus she has been working with members of the Sto:lo and Sts'ailes First Nation in British Columbia to document language and cultural revitalization since 2007.

Sue Montabello is a passionate teacher, mentor and community leader. She has worked collaboratively with Simon Fraser University for over 20 years to facilitate teacher education through her various roles including Faculty Associate, Sessional Instructor, and Cohort Facilitator.

Paula Rosehart is the Graduate Diploma in Education, Field Programs, Academic Coordinator, at Simon Fraser University in British Columbia, Canada. She holds a PhD, 
M.Ed., and a Graduate Diploma in Arts Education from Simon Fraser University. Her research pertains to teacher education and in particular to the somatics/aesthetics of teacher education (Somataphorical Inquiry), teacher-inquiry, arts-based curriculum development, holistic education, and creative, aesthetic re-representation of learning and teaching.

\section{References}

Arao, B., \& Clemens, K. (2013). From safe spaces to brave spaces: A new way to frame dialogue around diversity and social justice. In L. M. Landreman (Ed.). The arts of effective facilitation; reflections from social justice educators (pp.135-150). Stylus Publishing.

Arizona Group (2006). Exploring the concept of dialogue in the self-study of teaching practices. In C. Kosnik, C. Beck, A. R. Freese, A. P. Samaras (Eds.). Making a difference in teacher education through self-study: Studies of personal, professional, and program renewal (pp. 51-63). Dordrecht: Springer.

Bakhtin, M. M. (1986). The problem of speech genres. In C. Emerson \& M. Holquist (Eds.), $M M$ Bakbtin: Speech genres and other late essays (pp. 60-102) (V. W. McGee, Trans.). Austin: University of Texas Press.

Barad, K. (2007). Meeting the universe halfway: Quantum physics and the entanglement of matter and meaning. Durham, NC: Duke University Press.

Battiste, M. (2013). Decolonizing education: Nourishing the learning spirit. Saskatoon, SK: Purich Publishing. Bhabha, H. K. (2004). The location of culture. New York: Routledge.

Block, P. (2009). Community: The structure of belonging. San Francisco: Berrett Koehler.

Bohm, D. (1996). On dialogue. New York: Routledge.

Brookfield, S.D. (1995). Becoming a critically reflective teacher. San Francisco: JosseyBass Publishers.

Brown, B. (2012). Daring greatly: How the courage to be vulnerable transforms the way we live, love, parent, and lead. New York: Gotham Books.

Borthwick, A. G. (1994). School-university-community collaboration: Establishing and maintaining partnerships for school improvement. (Unpublished doctoral dissertation). Kent State University, Ohio.

Borthwick, A., Stirling, T., Nauman, A. D., \& Cook, D. L. (2003). Achieving successful schooluniversity collaboration. In Urban Education. 38(3), 330-371.

Captuo, J. D. (1977). Deconstruction in a nutshell: A conversation with Jacques Derrida. New York: Fordham University Press.

Catelli, L. A., Costello, J., \& Padovano, K. (2000). Action research in the context of a schooluniversity partnership: its values, problems, issues and benefits. Educational Action Research. 8 (2), 225-242.

Chan, C. (2016). School-University partnerships in English language teacher education: Tensions, complexities and the politics of collaboration. Switzerland: Springer.

Cochran-Smith, M., \& Lytle, S.L. (2009). Inquiry as stance: Practitioner research in the next generation. New York: Teachers College Press.

Dana, N., \& Yendol-Hoppey, D. (2014). Becoming the best teacher and researcher you can be. In The reflective educator's guide to classroom research (3rd ed.). California: Corwin Press. 
Day, C., \& Smethem, L. (2010). Partnerships between schools and higher education. In P. Peterson, B. E. Baker, \& B. McGaw (eds.). International Encyclopedia of Education (3rd ed.) pp. 757-763. Toronto: Elsevier.

Deleuze, G., \& Guattari, F. (1987). A thousand plateaus: Capitalism and schizophrenia. (B. Massumi, Trans.). Minneapolis: University of Minnesota Press.

East, K., Fitzgerald, L. M., \& Heston, M. L. (2009). Talking teaching and learning: Using dialogue in self-study. In D. L. Tidwell, M. L. Heston, \& L. M. Fitzgerald, (Eds.). Research methods for the self-study of practice, (pp. 51-64). Dordrecht: Springer.

Eliot, T. S. (1942). T.S. Eliot: Four quartets: Little gidding. Retrieved from http://allspirit.co.uk/ gidding.html

Fels, L., \& Belliveau, G. (2008). First flight into performative inquiry. In Exploring curriculum: Performative inquiry, role drama and learning. pp. 15-37. Vancouver, BC: Pacific Educational Press.

Foucault, M. (1977). Discipline and punish: The birth of the prison. New York: Vintage Books.

Greene, M. (1988). Dialectic of freedom. New York: Teachers College Press.

Grimmett, P. P. (2014). Inquiry-based teacher education thirty years on. Paper presented at the Year of Teacher Education seminar. University of British Columbia, Vancouver, B.C.

Groundwater-Smith, S., Mitchell, J., Mockler, N., Ponte, P., \& Ronnerman, K. (2013). Facilitating practitioner research: Developing transformational partnerships. New York: Routledge

Heron, J., \& Reason, P. (1997). A participatory inquiry paradigm. Qualitative Inquiry, 3(3), 274-294.

Hill, C. M. (2017). More-than-reflective practice: Becoming a diffractive practitioner. Teacher Learning and Professional Development, 2(1), 1-17.

Hill, C., \& MacDonald, M. (2016). Implementation and impact of experiential learning in a graduate level teacher education program: An example from a Canadian university. Global Education Review, 4(3), 54-69.

Himley, M. (2000). The value/s of oral inquiry or “you just had to be there!” In M. Himley \& P. Carini (Eds.), From another angle: Children's strengths and school standards (pp. 199-210). New York: Teachers College Press.

Hopkins, D., West, M., \& Ainscow, M. (1998). Improving the quality of education for all. London: David Fulton Publishers.

Jackson, A. Y., \& Mazzei, L. (2012). Thinking with theory in qualitative research. New York: Routledge.

Kersh, M. E., \& Masztal, N. B. (1998). An analysis of studies of collaboration between universities and K-12 schools. The Educational Reform, 62, 218-225.

Kessler, Rachel. (2000). The teaching presence. Virginia Journal of Education, 94(2), 7-10.

Kohl, H. R. (1995). I won't learn from you: And other thoughts on creative maladjustment. New Press.

Langan, D., \& Morton, M. (2014). Reflecting on community/academic "collaboration": The challenge of "doing" feminist participatory action research. In R. Berman (ed.). Corridor talk: Canadian feminist scholars share stories of research partnerships. pp. 17-38 Toronto: Inanna Publication.

Lave, J., \& Wenger, E. (1991). Situated learning. Legitimate peripheral participation. New York, NY: Cambridge University Press.

Leggo, C. (2008). Autobiography: Researching our lives and living our research. In S. Springgay, R. Irwin, C. Leggo, \& P. Gouzouasis (Eds.), Being with a/r/tography (pp. 3-23). Rotterdam: Sense Publishers. 
Malaguzzi, L. (1994). Your image of the child: Where teaching begins. Early Childhood Educational Exchange, 96, 52-61.

Mandell, N., \& King, K. (2014). Emotional labour and feeling rules in academic and community research partnerships. In R. Berman (ed.). Corridor talk: Canadian feminist scholars share stories of research partnerships. Toronto: Inanna Publication.

McDiarmid, G. W. (2008). Rethinking teacher capacity. In M. Cochran-Smith, S. Feiman-Nemser, D. J. McIntyre, \& K. E. Demers (Eds.), Handbook of research on teacher education, (pp. 134-156). New York: Routledge.

Miller, J. P. (2010). Whole child education. Toronto: University of Toronto Press.

Miller, J. P. (2007). The holistic curriculum (2nd ed.). Toronto: University of Toronto Press.

Noddings, N. (2002). Starting at home: Caring and social policy. Berkeley: University of California Press.

Noddings, N. (1992). The caring teacher: The challenge to care in schools. Columbia University Press.

Noddings, N. (1984). Caring: A feminine approach to ethics and moral education. Berkeley: University of California Press.

Palmer, P. (2009). A Hidden wholeness. The journey towards an undivided life. San Francisco: Jossey-Bass.

Palmer, P. (2007). The courage to teach: Exploring the inner landscape of a teacher's life. San Francisco: JosseyBass.

Rosehart, P. (2013). Learning to move, moving to learn: Metaphorical expressions in teacher education. (Unpublished doctoral dissertation). Simon Fraser University.

Scharmer, O. (2009). Theory U: Leading from the future as it emerges. San Francisco: BerrettKoehler.

Simon Fraser University (n.d.). Mission statement. Retrieved from https://www.sfu.ca/pres/mission. html

Tidwell, D., Heston, M., \& Fitzgerald, L. (2009). Talking teaching and learning: Using dialogue in self-study. In D. Tidwell, M. Heston, \& L. Fitzgerald (Eds.). Research methods for the self-study of practice (pp. 52-72). Dordrecht: Springer.

Van Katwyk, T., \& Case, R. A. (2016). From suspicion and accommodation to structural transformation: Enhanced scholarship through enhanced community-university relations. Engaged Scholar Journal, 2(2), 25-43.

Waldrop, M. M. (1992). Complexity: The emerging science at the edge of order and chaos. New York: Simon \& Schuster.

Wheatley, M. J. (2009). Turning to one another: Simple conversations to restore bope to the future. San Francisco: Berrett-Koehler Publishers.

Whitehead, A. N. (1967). The aims of education and other essays. New York: The Free Press.

Whitford, B. L. (1996). Collaborations are relationships. In Policy Studies Associates, Learning to collaborate: Lessons from school-college partnerships in the excellence in education program (pp. 2-3). Washington, DC: Policy Studies Associates.

Yappa , L. (1998). The poverty discourse and the poor in Sri Lanka. Transactions of the Institute of British Geographers, 23 (1), 95-115. 